\title{
Impact of Climate Change on Indian Agriculture \& Its Mitigating Priorities
}

\author{
Manas Ranjan Senapati ${ }^{1,}$, Bhagirathi Behera ${ }^{2}$, Sruti Ranjan Mishra ${ }^{3}$ \\ ${ }^{1}$ Department of Chemistry, Trident Academy of Technology, Bhubaneswar, Odisha, India \\ ${ }^{2}$ Former Director Environment, Government of Odisha \\ ${ }^{3}$ Department of Chemistry, C. V. Raman College of Engineering, Bhubaneswar, India \\ *Corresponding author: dr_senapati@yahoo.com
}

Received October 10, 2013; Revised October 25, 2013; Accepted November 12, 2013

\begin{abstract}
This paper considers the needed adaptation measures including changes needed for mitigation to improve agriculture sector in India. It considers the likely changes that climate change will bring in temperature, precipitation and extreme rainfall, drought, flooding, storms, sea-level rise and environmental health risks and the overall impact on agriculture. The agricultural sector is the major source of employment in India. Climate change has adverse impacts on agriculture, hydropower, forest management and biodiversity. Anticipated impacts on agriculture from climate change and its various aspects have been studied.
\end{abstract}

Keywords: adaptation, precipitation, global warming, biodiversity, rurbanisation

Cite This Article: Manas Ranjan Senapati, Bhagirathi Behera, and Sruti Ranjan Mishra, "Impact of Climate Change on Indian Agriculture \& Its Mitigating Priorities.” American Journal of Environmental Protection 1, no. 4 (2013): 109-111. doi: 10.12691/env-1-4-6.

\section{Introduction}

Weather is the condition of the atmosphere at a particular place and time. It is characterized by parameters such as temperature, humidity, rain and wind. Climate is the long term pattern of weather conditions for a given area. Climate change refers to a statistically significant variation in either the mean state of the climate or its variability, persisting for an extended period. India is home to extraordinary variety of climatic regions, ranging from tropical in the south to temperate and alpine in the Himalayan north, where elevated regions receive sustained winter snowfall. The nation's climate is strongly influenced by the Himalayas and the Thar Desert. Four major climatic groupings predominate into which fall seven climatic zones which are defined on the basis of temperature and precipitation.

Climate change is the most important global environmental challenge facing humanity with implications for natural ecosystems, agriculture \& health $[1,2]$. The perusal of general circulation models (GCM s) on climate change indicate that rising levels of greenhouse gases (GHGs) are likely to increase the global average surface temperature by $1.5-4.5^{\circ} \mathrm{C}$ over the next 100 years. The difference of average temperature between the last ice age and present climate is $6^{\circ} \mathrm{C}$. This will raise sea-levels, shift climate zones pole ward, decrease soil moisture and storms. Global warming is predicted to affect agricultural production (Table $1 \&$ Table 2).

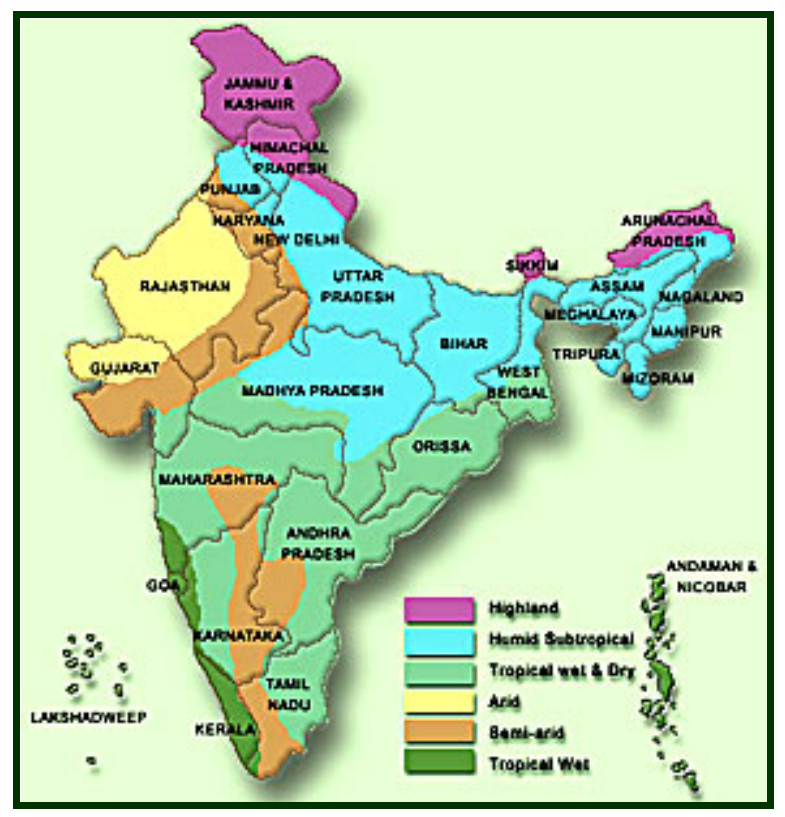

Figure 1. Seven climatic zones of India

Table 1. Rice yield in MT (Source-USDA, Foreign Agricultural Service)

\begin{tabular}{|c|c|c|c|c|c|}
\hline Country & $1999-2000$ & $2000-2001$ & $2001-2002$ & $2002-2003$ & $2003-2004$ \\
\hline India & 89,700 & 84,871 & 91,600 & 80,000 \\
\hline China & 138,936 & 131,536 & 124,320 & 123,200 \\
\hline Bangladesh & 23,066 & 25,086 & 25,500 & 26,000 \\
\hline Australia & 787 & 1,259 & 930 & 965,187 \\
\hline World Total & 409,200 & 397,354 & 396,588 & 39,230 \\
\hline
\end{tabular}


Table 2. Year wise average yield of wheat and rice at all India level (Kgs per hectare) (Source-USDA, Foreign Agricultural Service)

\begin{tabular}{|c|c|c|}
\hline Year & Wheat & Rice \\
\hline $1999-2000$ & 2778 & 1986 \\
\hline $2000-2001$ & 2708 & 1901 \\
\hline $2001-2002$ & 2762 & 2079 \\
\hline $2002-2003$ & 2610 & 1744 \\
\hline $2003-2004$ & 2713 & 2077 \\
\hline
\end{tabular}

More detailed analysis of rice yields by the International Rice Research Institute forecast 20\% reduction in yields over the region per degree celsius of temperature rise. Rice becomes sterile if exposed to temperatures above 35 degrees for more than one hour during flowering and consequently produces no grain. The rising temperatures will adversely affect the world's food production and India would be the hardest hit, according to the analysis by the Universal Ecological Fund (FEU-US). The crop yield in India, the second largest world producer of rice and wheat, would fall up to 30 percent by the end of this decade. Carbon dioxide $\left(\mathrm{CO}_{2}\right)$ is the most important anthropogenic gas the growth-rate of which was larger during the last 10 years at the rate of 1.9 ppm per year. At present, the amount of $\mathrm{CO}_{2}$ in the atmosphere is $387 \mathrm{ppm}$. In comparison, the amount of oxygen is 210, $000 \mathrm{ppm}$. Some other gases that contribute to warming include methane, nitrous oxide and chlorofluorocarbons. The GHGs once emitted stay in the atmosphere for decades.

\section{Impact of Elevated $\mathrm{CO}_{2}$, Temperature \& Precipitation on Agriculture}

Some predict positive impacts on agriculture from climate change like increased temperatures and higher carbon dioxide levels [3]. Increased concentrations of $\mathrm{CO}_{2}$ may boost crop productivity, only where moisture is not a constraint. Higher levels of $\mathrm{CO}_{2}$ can stimulate photosynthesis in certain plants (30-100 per cent). Experimental observations confirm that when plants absorb more carbon grow bigger and more quickly. This is particularly true for C3 plants (so called because the product of their first biochemical reactions during photosynthesis has three carbon atoms). Increased $\mathrm{CO}_{2}$ tends to suppress photo-respiration in these plants, making them more water-efficient. The response of C4 plants would not be as dramatic. C3 plants correspond to midlatitude food staples like wheat, rice and soy bean whereas C4 plants correspond to low-altitude crops like maize, sorghum \& sugarcane. The impact on yields of lowlatitude crops is more difficult to predict while the midlatitude yields may be reduced by $10-30$ per cent due to increased summer dryness. The effects of an increase in carbon dioxide would be higher on C3 crops (such as wheat) than on C4 crops (such as maize), because the former is more susceptible to carbon dioxide shortage. Moreover, the protein content of the grain decreases under combined increases of temperature and $\mathrm{CO}_{2}$. For rice, the amylase content of the grain-a major determinant of cooking quality-is increased under elevated $\mathrm{CO}_{2}$. With wheat, elevated $\mathrm{CO}_{2}$ reduces the protein content of grain and flour by $9-13 \%$. Concentrations of Fe and $\mathrm{Zn}$ which are important for human nutrition would be lower.

A $10-15 \%$ increase in monsoon precipitation in many regions, a simultaneous precipitation decline of $5-25 \%$ in drought-prone central India and a sharp decline in winter rainfall in northern India are also projected. This implies changes in output of winter wheat and mustard crops in northwestern India. A decrease in number of rainy days (5-15 days on an average) is expected over much of India, along with an increase in heavy rainfall days in the monsoon season (Indian Institute of Tropical Meteorology, Ministry of Earth Sciences, Government of India). These changes are expected to increase the vulnerability of Indian agriculture. This is particularly important in India, where agriculture is highly sensitive to monsoon variability as $65 \%$ of the cropped area is rain-fed $[4,5]$. Changes in temperature and precipitation could have a significant impact on more than 350 million people who are dependent on rain-fed agriculture.

The agricultural sector is a driving force in the GHG emissions and land use effects. The three major causes of the increase in GHGs observed over the past 250 years have been fossil fuels, land use and agriculture. The agricultural processes (rice cultivation, enteric fermentation in cattle) comprise $54 \%$ of methane emissions, $80 \%$ of nitrous oxide emissions and major percentage of carbon dioxide.

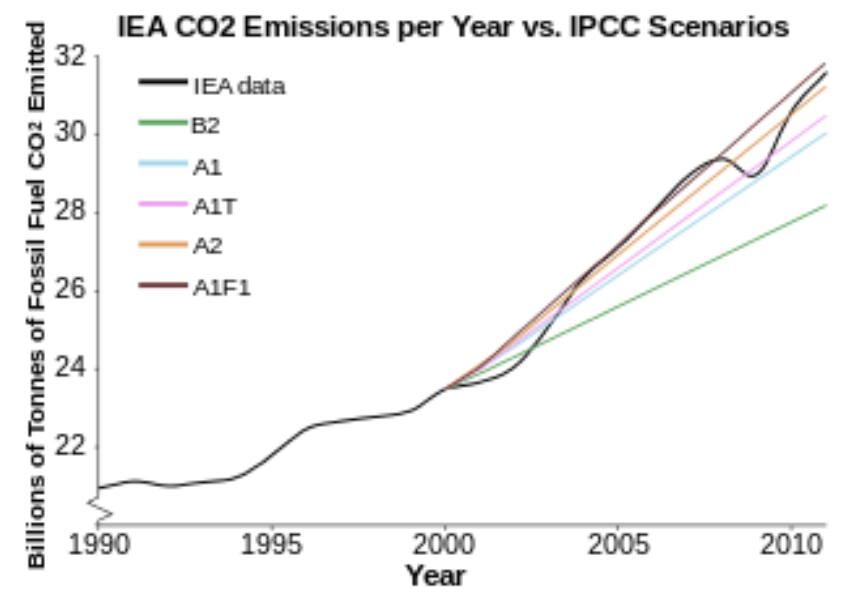

\section{Role of IPCC \& Climate Change Mitigation}

The Intergovernmental Panel on Climate Change (IPCC), an international body of over 3000 experts, indicates that rice and wheat production of India will drop significantly because of climate change. A $1.5^{\circ} \mathrm{C}$ rise and two $\mathrm{mm}$ increase in precipitation could result in a decline in rice yields by 3-15 per cent. According to IPCC's Third Assessment Report (TAR), “The importance of climate change impacts on grain and forage quality emerges from new research.” In its Fourth Assessment Report (AR4), published in 2007, the IPCC projects that, without further action to reduce GHG emissions, the global average surface temperature is likely to rise by a further $1.8-4.0^{\circ} \mathrm{C}$ this century, and by up to $6.4^{\circ} \mathrm{C}$ in the worst case scenario. The ultimate impact of loss of food grain production would be to use hard currency to increase food imports [6] Food insecurity and malnutrition will affect the overall health status of millions of people, with implications for infant mortality in large number. Increased human interference in modern technology based agriculture has 
resulted in decrease in diversity at all levels in agro ecosystem.

The most serious climate change risk to the Indian economy and its people is the increased intensity, frequency and geographical coverage of drought. Higher temperatures, increased evapo-transpiration and decreased winter precipitation may bring about more droughts. The possibility of winter drought will increase in certain areas. Climate change is expected to increase the severity of flooding in many Indian river basins, especially those of the Godavari and Mahanadi along the eastern coast [7]. The third most important risk is that of cyclonic storms, storm surge and coastal inundation. A sea surface temperature rise of $2-4^{\circ} \mathrm{C}$, as anticipated in the Indian ocean over the century, is expected to induce a 10-20 percent increase in cyclone intensity (National Disaster Management Authority, Government of India). The 1999 Odisha super-cyclone killed more than 10, 000 people and devastated buildings across 10 coastal and 6 inland districts. This disaster was due to the combination of storm surge, cyclonic winds and coastal flooding. The cyclone dumped heavy torrential rain over southeast India, causing record breaking flooding in the low-lying areas. The storm surge was 26 feet (8 meters). struck the coast of Odisha, traveling up to $20 \mathrm{~km}$ inland. 17,110 km² $(6,600$ $\mathrm{mi}^{2}$ ) of crops were destroyed, and an additional 90 million trees were either uprooted or had snapped.

The climate change mitigation generally involves reductions in human emissions of GHGs which can be achieved by increasing the capacity of carbon sinks. Use of renewable energy and nuclear energy and expanding forests are the mitigating priorities. Prof. Sir Nicholas Stern in his review predicts that living conditions and livelihood opportunities of millions of people may be affected by climatic variability and hence biodiversity loss [8]. Stern also forecasts that sea level rise could cause major displacement of people from coastal areas. Climate change demands an international response, based on a shared understanding of long term goals and agreement on frameworks for action.

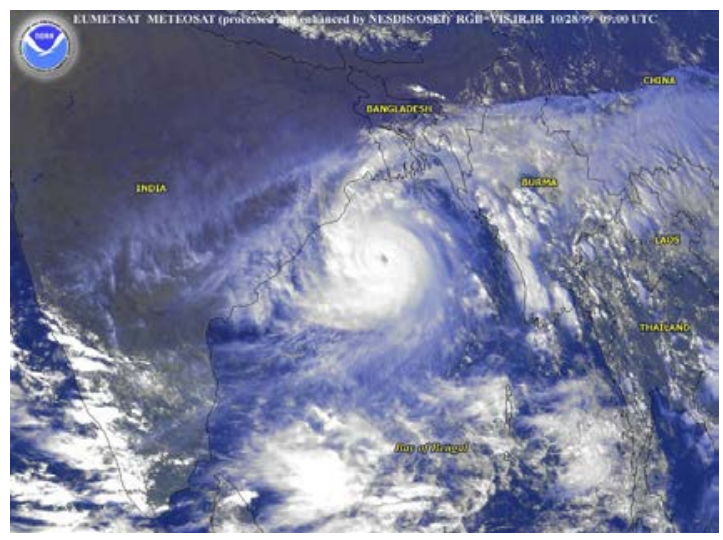

Figure 2. Odisha Super-cyclone 1999

\section{Conclusion}

It is estimated that India needs $320 \mathrm{MT}$ of food grains by the year 2025. For a country like India, sustainable agricultural development is essential not only to meet the food demands, but also for poverty reduction through economic growth by creating employment opportunities in non-agricultural rural sectors.

It is possible that climate change may force the pace of rural-urban migration (rurbanisation) over the next few decades [9]. The ongoing agrarian crisis in rural India could be catalyzed by climate change into a migratory rout, driven by greater monsoon variability, endemic drought, flooding and resource conflict.

The role of Science \& Technology cannot be ignored. Right kind of technologies and policies are required to strengthen the capacity of communities to cope effectively with both climatic variability and changes [10]. Adaptive actions may be taken to overcome adverse effects of climate change on agriculture. Innovative agricultural practices and technologies can play a role in climate mitigation and adaptation. This adaptation and mitigation potential is nowhere more pronounced than in developing countries where agricultural productivity remains low; poverty, vulnerability and food insecurity remain high; and the direct effects of climate change are expected to be especially harsh. Creating the necessary agricultural technologies and harnessing them to enable developing countries to adapt their agricultural systems to changing climate will require innovations in policy and institutions as well. In this context, institutions and policies are important at multiple scales. Noteworthy interventions to reduce adverse impacts of climate change include:

- improvement in forecasting \& early warning systems

- establishing hazard \& vulnerability mapping

- augmenting public awareness

- creating community-based forest management and afforestation projects

- improvement in irrigation

\section{References}

[1] Parikh, J K \& Parikh, K (2002), Climate change: India’s perceptions, positions, policies and possibilities, OECD, Paris.

[2] Senapati, M.R. (2009),”Vulnerabilities to climate change”, Kurukshetra, A Journal published by Ministry of Rural Development, Govt. of India.

[3] Mendelssohn, Robert et al. (1994), "The impact of climate change on agriculture: A Ricardian Analysis,” American Economic Review Vol 84, No4, pp 753-771.

[4] Chang, J H (1987),’The Indian summer monsoon” Geographical Review 57(3):373-396.

[5] Zickfeld, K et al. (2005), "Is the Indian summer monsoon stable against global change?” Geophysical Research Letters Vol 32, L 15707.

[6] Rosenzweig, C \& Parry, M.L. (1994) "Potential impact of climate change on world food supply”, Nature, 367 (6450), pp 133-138.

[7] Gosain, A K et al. (2006), "Climate change impact assessment on hydrology of Indian river basins”, Current Science Vol 90, No 3, 10 February 346-353.

[8] www.sternreview.org.uk

[9] Revi, A (2008),"Climate change risk: an adaptation and mitigation agenda for Indian cities”, Environment \& Urbanization Vol 20(1):207-229.

[10] Socolow, R \& Pacala, S (2004),”Stabilization wedges: solving the climate problem for the next 50 years with current technologies", Science Vol 305, No 5686, 13 August, 968-972. 